\title{
PENGARUH FAKTOR-FAKTOR MOTIVASI TERHADAP KINERJA PEGAWAI DI PT. BANK BNI SYARIAH KANTOR CABANG JAKARTA BARAT DAN BOGOR
}

\author{
Atika Dyah Perwita ${ }^{*}$, Rita Nurmalina ${ }^{* *}$, dan Joko Affandi***) \\ ${ }^{*}$ Sekolah Bisnis, Institut Pertanian Bogor \\ Jl. Raya Pajajaran, Bogor 16151 \\ **) Departemen Agribisnis, Fakultas Ekonomi dan Manajemen, Institut Pertanian Bogor \\ Jl. Kamper Wing 4 Level 5 Kampus IPB, Bogor, Jawa Barat 16680 \\ ${ }^{* * *}$ PPM Manajemen \\ Jl. Menteng Raya No. 9 Jakarta Pusat 10340
}

\begin{abstract}
BNI Syariah as a shariah public bank is committed to fulfill and complete the plan in developing the human resource from time to time to support the performance and provide the best service for the stakeholder and also to create world class human capital. The organization's effort to increase the productivity both in financial and non financial aspect has experienced various constraints; one of them is the declining of the employee's performance due to the declination of the motivation. The objective of the research is to study the most influential motivation factors to the employee's performance. The data is collected using the annual report of the company, conducted interviews and questionnaire with differential semantic scale. The data is analyzed with Partial Least Square (PLS). The result shows that both motivation and hygiene factor influence the employee's performance. The most influenced factor in both offices is hygiene. The most dominant indicator in hygiene factor reflection in developing the performance of the employee is the working condition and interpersonal relationship.
\end{abstract}

Keywords: hygiene factor, performance, extrinsic motivation, intrinsic motivation motivator

\begin{abstract}
ABSTRAK
BNI Syariah sebagai Bank Umum Syariah berkomitmen untuk memenuhi dan menyempurnakan rencana pengembangan SDM dari waktu ke waktu untuk menunjang kinerja dan layanan yang terbaik kepada para stakeholder serta mewujudkan world class human capital. Usaha organisasi untuk meningkatkan produktivitasnya baik dalam aspek finansial maupun non finansial mengalami berbagai hambatan, salah satunya adalah penurunan kinerja karyawan yang disebabkan oleh penurunan tingkat motivasi karyawan. Tujuan penelitian ini adalah mengkaji faktor-faktor motivasi yang paling berpengaruh terhadap kinerja pegawai. Teknikpengumpulan data menggunakan data laporan tahunan perusahaan, wawancara dan Kuesioner dengan skala semantic differential. Analisis data dilakukan dengan metode Partial Least Square (PLS). Hasil analisis pengaruh faktor-faktor motivasi terhadap kinerja menunjukkan bahwa motivator dan hygiene factor keduanya berpengaruh terhadap kinerja pegawai. Adapun faktor-faktor yang paling berpengaruh terhadap kinerja pegawai PT. Bank BNI Syariah Kantor Cabang (KC) Jakarta Barat dan Bogor adalah hygiene factor. Indikator yang paling dominan dalam merefleksikan hygiene factor dalam membangun kinerja pegawai adalah kondisi kerja dan hubungan interpersonal.
\end{abstract}

Kata kunci: hygiene factor, kinerja, motivasi ekstrinsik, motivasi intrinsik, motivator

\footnotetext{
${ }^{1}$ Alamat Korespondensi:

Email: tika.perwita@gmail.com
} 


\section{PENDAHULUAN}

Bisnis perbankan adalah bagian yang tidak dapat dipisahkan dari pelayanan dan kepercayaan. Persaingan antar bank yang semakin ketat menuntut para pemain pada industri perbankan untuk memberikan pelayanan terbaik kepada para nasabah. Pelayanan prima yang diberikan oleh perusahaan akan menumbuhkan kepercayaan nasabah sehingga diharapkan dapat meningkatkan pencapaian bisnis bank tersebut (Wibowo, 2015). Perbankan sebagai industri jasa sangat memerlukan pegawai yang memiliki kinerja baik dalam menjalankan aktivitas bisnis perusahaan. Faktor sumber daya manusia menduduki peran penting dalam kemajuan suatu organisasi karena tercapainya tujuan organisasi sangat tergantung pada aktivitas para anggota yang ada di dalam organisasi tersebut (Suprapti, 2008).

BNI Syariah sebagai Bank Umum Syariah lahir pada 19 Juni 2010. Untuk menunjang kinerja dan layanan yang terbaik kepada para stakeholder, divisi HCD (Human and Capital Development) BNI Syariah mencari calon karyawan dengan usia muda yang mampu bekerja secara profesional dan produktif. BNI Syariah berkomitmen untuk memenuhi dan menyempurnakan rencana pengembangan SDM dari waktu ke waktu untuk mewujudkan world class human capital. Sumber Daya Manusia (SDM) BNI Syariah tidak hanya harus jujur dan berintegritas, tetapi juga menjadi SDM yang tangguh, unggul dan yang mampu bersaing tidak hanya di tingkat domestik, tetapi juga di tingkat regional maupun internasional.

Menurut Mangkunegara (2004), faktor yang memengaruhi pencapaian kinerja adalah faktor kemampuan (ability) dan faktor motivasi (motivation). Terutama di sektor jasa, motivasi karyawan sangat penting dalam hal memastikan terus-menerus kualitas layanan (Hays dan Hill, 1999). Manajemen beserta seluruh jajaran pegawai bank harus dapat memberi jasa yang memuaskan kepada nasabahnya agar dapat bertahan dan berkembang, caranya adalah memahami persepsi nasabah mengenai jasa bank serta menerapkannya sesuai dengan apa yang diinginkan nasabah (Kurniawan, 2009). Para karyawan dituntut untuk dapat melaksanakan tugas yang dibebankan kepadanya secara profesional, bekerja keras, disiplin, jujur, loyalitas tinggi, dan penuh dedikasi untuk keberhasilan pekerjaannya (Hamid dan Rowi, 2003).
Perkembangan kinerja perbankan syariah di Indonesia sangat pesat. Industri perbankan syariah menunjukkan akselerasi pertumbuhan yang tinggi dengan ratarata sebesar $40,2 \%$ per tahun dalam periode tahun 2007 sampai 2011. Sementara pertumbuhan rata-rata perbankan nasional hanya sebesar $16,7 \%$ per tahun. Pada tahun 2013, terjadi peningkatan persentase pertumbuhan pada aset dan pembiayaan yang dicapai BNI Syariah dibanding tahun sebelumnya. Dari sisi finansial, BNI Syariah berhasil membukukan total aset sebesar Rp14,71 triliun. Selain itu pertumbuhan pembiayaan juga meningkat sebesar $47,30 \%$ menjadi Rp11,24 triliun. Pencapaian ini menjadi indikator bahwa kepercayaan masyarakat terhadap BNI Syariah kian meningkat dari tahun ke tahun.

Sejak tahun 2013, pertumbuhan aset dan pembiayaan yang dicapai BNI Syariah mulai menurun menjadi lebih rendah dibandingkan pertumbuhan aset dan pembiayaan pada tahun-tahun sebelumnya. Pada tahun 2015, semua indikator kinerja perusahaan selain laba mengalami penurunan pertumbuhan yang cukup besar dibanding tahun sebelumnya. Pertumbuhan aset, DPK, dan pembiayaan masing-masing mengalami penurunan pertumbuhan sebesar $14,43 \% ; 22,48 \%$ dan $15,68 \%$ dibanding tahun lalu. Sebaliknya, pertumbuhan laba mengalami kenaikan hanya sebesar $1 \%$ dari tahun lalu sebesar 38,98\% menjadi 39,98\% pada akhir tahun 2015.

Penurunan kinerja organisasi dapat terjadi karena penurunan kinerja pegawai yang dipengaruhi oleh berbagai faktor, termasuk motivasi. Adanya beragam faktor yang dapat memengaruhi motivasi pegawai sangat penting untuk diperhatikan perusahaan karena dapat berdampak pada pencapaian tujuan perusahaan. Motivasi kerja sangat penting bagi karyawan karena motivasi dapat menggerakkan individu untuk bekerja lebih giat dan dengan kualitas kerja yang lebih baik sehingga kinerja karyawan dapat meningkat dan pada akhirnya berdampak pada meningkatnya kinerja organisasi (Lusthaus, 2002). Beberapa penelitian mengenai pengaruh faktor-faktor motivasi terhadap kinerja pegawai sudah dilakukan. Dampak yang positif ditunjukkan oleh hasil penelitian Muslih et al. (2012) yang memperlihatkan bahwa hygiene factor berpengaruh positif dan signifikan terhadap kinerja pegawai sedangkan motivator berpengaruh signifikan secara tidak langsung terhadap kinerja pegawai melalui kepuasan kerja. Berbeda dengan hasil penelitian yang 
dilakukan oleh Noermijati (2008) dengan alat analisis Structural Equation Modelling (SEM) bahwa motivator mempunyai pengaruh langsung terhadap kinerja, sedangkan hygiene factor mempunyai pengaruh secara tidak langsung terhadap kinerja melalui kepuasan kerja. Penelitian oleh Handayani et al. (2014) dengan alat analisis regresi linier berganda menunjukkan bahwa faktor-faktor motivasikerja baik motivator maupun hygiene factor memiliki pengaruh simultan atau bersama-sama terhadap kinerja. Perbedaan penelitian ini dengan penelitian-penelitian sebelumnya adalah alat analisis yang digunakan, yaitu menggunakan PLS (Partial Least Square) dan terdapat second order factor. Oleh karena itu, peneliti merasa perlu untuk melakukan kajian dan analisis mengenai faktor-faktor motivasi yang berpengaruh terhadap kinerja pegawai di PT. Bank BNI Syariah Kantor Cabang Jakarta Barat dan Bogor.

\section{METODE PENELITIAN}

Penelitian ini dilakukan di PT. Bank BNI Syariah Kantor Cabang Jakarta Barat dan Bogor. Pengambilan data dimulai pada bulan April-Mei 2016 dengan menggunakan instrumen berupa kuesioner yang diisi oleh seluruh karyawan. Data yang diperlukan dalam penelitian ini berasal dari dua sumber, yaitu data primer dan data sekunder. Data primer diperoleh dari kuesioner yang diisi oleh responden yaitu seluruh karyawan di PT. Bank BNI Syariah KC Jakarta Barat dan Bogor (Tabel 1), sedangkan data sekunder diperoleh dari data perusahaan yang digunakan untuk menunjang penelitian ini. Narasumber untuk penelitian ini adalah populasi karyawan kontrak maupun karyawan tetap di PT. Bank BNI Syariah Jakarta Barat dan Bogor yang masingmasing berjumlah 41 orang dan 33 orang dari seluruh divisi. Penelitian ini menggunakan skala semantic differential untuk mengukur persepsi karyawan.

Tabel 1. Jumlah responden

\begin{tabular}{llc}
\hline \multicolumn{1}{c}{ Jenjang Jabatan } & Kantor Cabang & Jumlah (orang) \\
\hline Manajer & Jakarta Barat & 3 \\
& Bogor & 3 \\
Supervisor/Penyelia & Jakarta Barat & 11 \\
& Bogor & 14 \\
Officer Development & Jakarta Barat & 3 \\
Program & Bogor & 4 \\
Asisstant & Jakarta Barat & 24 \\
Development & Bogor & 32 \\
Program & & \\
\hline \multicolumn{2}{c}{ Jumlah } & 94 \\
\hline
\end{tabular}

Penggunaan analisis kualitatif deskriptif pada penelitian ini membuat penyajian data lebih mudah dalam memahami fenomena yang dialami oleh subjek penelitian dengan cara deskriptif dalam bentuk katakata dan bahasa pada suatu konteks (Fajri, 2016). Data ini berupa keterangan-keterangan seperti sejarah perusahaan, perencanaan, serta strategi yang dilakukan untuk memasarkannya (Kolina dan Mustamu, 2013). Untuk memperoleh hasil seberapa besar pengaruh faktor-faktor motivasi terhadap kinerja pegawai, dapat dilakukan perhitungan atau pengolahan data dengan menggunakan program PLS karena tidak menuntut sampel dalam jumlah besar dan direkomendasikan antara 30-100 sampel seperti yang dipaparkan dalam Ghozali dan Latan (2015). Evaluasi model dalam SEM-PLS menggunakan program SmartPLS 2.0 sangat berguna untuk memprediksi hubungan antara variabel dependen dari beberapa variabel independen. PLS dapat menemukan indikator dari variabel independen yang juga relevan untuk variabel dependen (Feng et al. 2008). Model PLS terdiri dari bagian struktural, yang mencerminkan hubungan antara variabel laten, dan komponen pengukuran, yang menunjukkan bagaimana variabel laten dan indikator mereka terkait (Haenlein dan Kaplan, 2004).

Model awal SEM-PLS yang diujikan pada penelitian ini dapat dilihat pada Gambar 1. Pada penelitian ini, hipotesis yang diujikan adalah sebagai berikut:

1. Variabel motivator berpengaruh positif dan signifikan terhadap kinerja pegawai

2. Variabel hygiene factor berpengaruh positif dan signifikan terhadap kinerja pegawai

Untuk setiap variabel laten memiliki beberapa indikator yang juga dipergunakan dalam menyusun pertanyaan pada kuesioner. Dari variabel-variabel yang diteliti diberikan definisi operasionalmya pada Tabel 2.

\section{HASIL}

\section{Analisis Deskriptif}

Narasumber pada penelitian ini yang berjumlah 94 orang digambarkan dengan beberapa kategori tertentu, seperti jenis kelamin, usia, jabatan, dan pendidikan terakhir. Hasilnya dapat dilihat pada Tabel 3. 


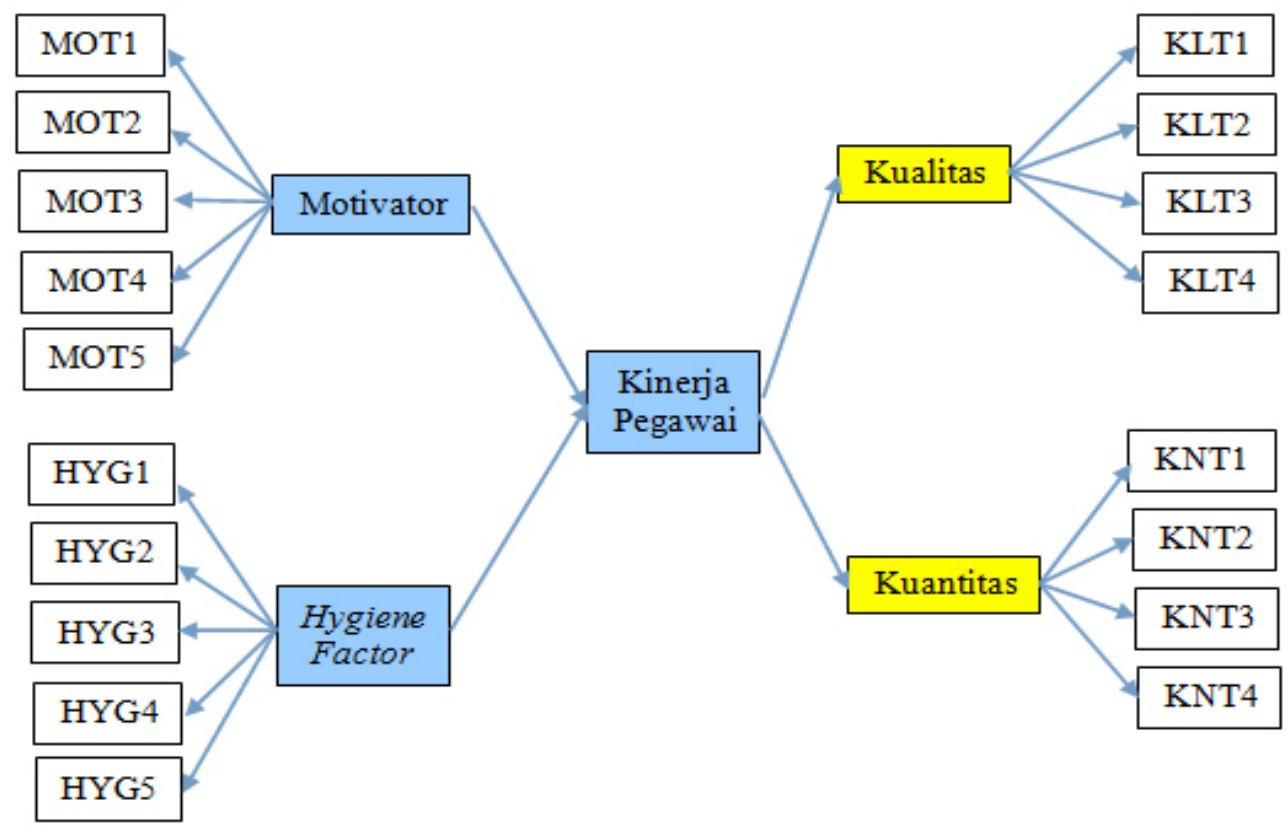

Gambar 1. Kerangka konseptual kinerja pegawai

Tabel 2. Definisi operasionalisasi variabel

\begin{tabular}{|c|c|c|c|}
\hline Variabel & $\begin{array}{c}\text { Definisi variabel } \\
\text { operasional }\end{array}$ & Batasan & Indikator \\
\hline $\begin{array}{l}\text { Motivasi Intrinsik } \\
\text { (X1) }\end{array}$ & $\begin{array}{l}\text { Motivasi atau dorongan untuk } \\
\text { melakukan sesuatu yang muncul } \\
\text { dari dalam diri seseorang tanpa } \\
\text { memerlukan rangsangan dari } \\
\text { luar. }\end{array}$ & $\begin{array}{l}\text { Teori dua faktor } \\
\text { Herzberg } \\
\text { (Herzberg et al. } \\
\text { 2008) }\end{array}$ & $\begin{array}{l}\text { 1. Pekerjaan itu sendiri (MOT1) } \\
\text { 2. Peluang untuk maju (MOT2) } \\
\text { 3. Pengakuan (MOT3) } \\
\text { 4. Prestasi yang diraih (MOT4) } \\
\text { 5. Tanggung jawab (MOT5) }\end{array}$ \\
\hline $\begin{array}{l}\text { Motivasi } \\
\text { Ekstrinsik (X2) }\end{array}$ & $\begin{array}{l}\text { Motivasi atau dorongan yang } \\
\text { muncul akibat adanya rangsangan } \\
\text { dari luar sehingga seseorang mau } \\
\text { melakukan sesuatu. }\end{array}$ & $\begin{array}{l}\text { Teori dua faktor } \\
\text { Herzberg } \\
\text { (Herzberg et al. } \\
\text { 2008) }\end{array}$ & $\begin{array}{l}\text { 1. Hubungan interpersonal (HYG1) } \\
\text { 2. Kondisi kerja (HYG2) } \\
\text { 3. Mutu penyeliaan (HYG3) } \\
\text { 4. Prosedur perusahaan (HYG4) } \\
\text { 5. Upah atau gaji (HYG5) }\end{array}$ \\
\hline $\begin{array}{l}\text { Kinerja pegawai } \\
(\mathrm{Y})\end{array}$ & $\begin{array}{l}\text { Hasil kerja baik secara kualitas } \\
\text { maupun kuantitas yang } \\
\text { dicapai oleh seseorang dalam } \\
\text { melaksanakan tugas sesuai } \\
\text { tanggung jawab yang diberikan. }\end{array}$ & $\begin{array}{l}\text { Kinerja pegawai } \\
\text { (Mangkunegara, } \\
\text { 2004) }\end{array}$ & $\begin{array}{l}\text { Kualitas (Y11) } \\
\text { 1. Tingkat kemampuan bekerja (KLT1) } \\
\text { 2. Kemampuan mengevaluasi (KLT2) } \\
\text { 3. Kemampuan menganalisis (KLT3) } \\
\text { 4. Ketepatan kerja (KLT4) } \\
\text { Kuantitas (Y12) } \\
\text { 1. Jumlah pemberian layanan (KNT1) } \\
\text { 2. Jumlah kesalahan (KNT2) } \\
\text { 3. Proses kerja (KNT3) } \\
\text { 4. Waktu menyelesaikan pekerjaan (KNT4) }\end{array}$ \\
\hline
\end{tabular}


Tabel 3. Karakteristik responden

\begin{tabular}{lcc}
\hline \multicolumn{1}{l}{ Karakteristik Responden } & Jumlah & Persentase (\%) \\
\hline Jenis Kelamin & & \\
Laki-laki & 40 & 42,55 \\
Perempuan & 54 & 57,45 \\
Usia & & \\
21-25 tahun & 25 & 26,60 \\
26-30 tahun & 59 & 62,76 \\
31-35 tahun & 5 & 5,32 \\
$>35$ tahun & 5 & 5,32 \\
Tingkat Pendidikan & & \\
D3 & 28 & 29,79 \\
S1 & 60 & 63,83 \\
S2 & 6 & 6,38 \\
Posisi & & \\
Asisstant & 56 & 59,57 \\
Officer & 7 & 7,45 \\
Supervisor & 25 & 26,6 \\
Manajer & 6 & 6,38 \\
\hline
\end{tabular}

\section{Kondisi Motivasi dan Kinerja Pegawai}

Persepsi responden secara umum terhadap variabel motivasi kerja intrinsik (X1), motivasi kerja ekstrinsik (X2), dan kinerja (Y) dapat dilihat dengan menghitung skor jawaban responden. Nilai rentang skala interval yang digunakan adalah 0,80 . Adapun nilai interval yang digunakan untuk mengklasifikasikan skor variabel pada kategori jawaban responden pada Tabel 4.

Tabel 4. Klasifikasi rentang kriteria

\begin{tabular}{clc}
\hline Skor & \multicolumn{1}{c}{ Kategori } & Kelas Interval \\
\hline 1 & Rendah Sekali & $1,00-1,80$ \\
2 & Rendah & $1,81-2,60$ \\
3 & Cukup & $2,61-3,40$ \\
4 & Tinggi & $3,41-4,20$ \\
5 & Sangat Tinggi & $4,21-5,00$ \\
\hline
\end{tabular}

Berdasarkan Tabel 5 dapat diketahui bahwa kondisi motivator sebagian besar pegawai sudah termasuk dalam kategori tinggi. Gambaran kondisi motivator sebagian besar karyawan sudah baik, terlihat dari nilai analisis rataan skor sebesar 3,83 yang berada pada skala tinggi. Namun, ada beberapa hal yang perlu diperhatikan dalam upaya mempertahankan kondisi motivator karyawan. Hal ini terkait dengan indikator pengakuan. Perusahaan perlu untuk memberikan penghargaan terhadap karyawan yang berprestasi dan menunjukkan hasil kerja yang memuaskan. Penghargaan juga perlu diberikan dari atasan kepada bawahan dalam bentuk pujian sehingga karyawan menjadi lebih termotivasi lagi dalam bekerja.

Pada Tabel 6 dapat dilihat gambaran kondisi hygiene factor sebagian besar karyawan sudah baik, dibuktikan dengan nilai analisis rataan skor sebesar 3,81 yang berada pada skala tinggi. Ada beberapa hal yang perlu diperhatikan dalam upaya mempertahankan hygiene factor karyawan. Hal ini terkait dengan indikator upah atau gaji dan mutu penyeliaan. Perusahaan perlu untuk memperhatikan tingkat kewajaran upah yang diberikan kepada karyawan sebagai imbalan terhadap pekerjaan yang mereka lakukan. Besar kecilnya upah akan meningkatkan ataupun menurunkan motivasi untuk bekerja sebagai penunjang kesejateraan.

Menurut Koesmono (2005), kompensasi merupakan hal yang penting dan dapat memberikan motivasi atau dorongan bagi pegawai untuk bekerja dengan baik sebagai imbal jasa sebagai imbal jasa dari pengusaha kepada karyawan yang telah memberikan kontribusinya bagi perusahaan. Pemberian gaji dapat menimbulkan ketidakpuasan bagi pegawai apabila dalam pelaksanaannya tidak adil dan tidak layak. Besar kecilnya gaji yang diberikan kepada pegawai harus disesuaikan dengan kontribusi tenaga dan pikiran yang diberikan oleh pekerja kepada perusahaan. Menurut Werther and Davis (1996), perusahaan harus berusaha keras membuat keadilan luar dan dalam. Internal menghendaki keadilan nilai pembayaran relatif sama dengan tugas yang diterima oleh pegawai sedangkan eksternal adalah pembayaran pekerja sebanding dengan pembayaran oleh perusahaan lain dipasaran tenaga kerja. Kompensasi dalam bentuk gaji yang diberikan perusahaan dengan adil dapat membuat pegawai merasa puas sehingga akan mampu memotivasi pegawai tersebut untuk meningkatkan kinerjanya sehingga tujuan perusahaan dapat tercapai (Muljani, 2002).

Perusahaan juga perlu memperhatikan kualitas penyeliaan dari atasan kepada bawahan dalam menilai prestasi kerja karyawan dengan cara membandingkan kinerja dengan uraian atau deskripsi pekerjaan dalam suatu periode tertentu. Penilaiaan kinerja perlu dilakukan seobyektif mungkin karena akan memotivasi karyawan dalam melakukan pekerjaannya (Koesmono, 2005). Penyeliaan yang baik harus dilakukan para manager selaku pemimpin divisi dalam melakukan peninjauan (review) secara berkala terhadap pekerjaan bawahannya (Hacker dan Doolen, 2007). 
Analisis persepsi responden terhadap kinerja digunakan untuk mengetahui gambaran kondisi kinerja karyawan yang bekerja di perusahaan. Penilaian persepsi mengenai kinerja berdasarkan nilai rataan skor masing-masing indikator kinerja. Hasil analisis persepsi karyawan mengenai kinerja dapat dilihat pada Tabel 7 .

Dari Tabel 7 dapat diketahui persepsi responden mengenai kinerja. Secara umum persepsi karyawan mengenai kinerja adalah baik. Hal ini dibuktikan dengan nilai analisis rataan skor sebesar 3,888 yang berada pada kategori tinggi yang berarti bahwa gambaran kondisi kinerja pegawai di PT. Bank BNI Syariah Jakarta Barat dan Bogor adalah baik. Namun perusahaan perlu untuk memperhatikan indikator-indikator pada kuantitas dan kualitas kerja karyawan. Hal ini mengenai waktu penyelesaian pekerjaan dan kemampuan karyawan dalam melakukan evaluasi. Perusahaan perlu untuk melihat secara bijaksana antara beban kerja yang harus diselesaikan oleh karyawan dengan waktu yang ditargetkan oleh perusahaan agar pekerjaan tersebut dapat diselesaikan. Jangka waktu yang cukup akan membuat karyawan mengerjakan pekerjaannya dengan lebih teliti dan dapat membagi waktunya dengan baik untuk membuat skala prioritas sehingga semua pekerjaan yang diberikan padanya dapat terselesaikan dengan baik. Perusahaan juga perlu memperhatikan kemampuan karyawan dalam melakukan evaluasi terhadap pekerjaan yang dilakukannya. Hal ini penting untuk menjaga kesadaran karyawan apakah sudah melakukan pekerjaannya dengan baik dan sesuai dengan standar operasional perusahaan ataukah belum. Sehingga diharapkan karyawan akan introspeksi diri dan terus melakukan perbaikan terkait pekerjaannya setiap hari.

Tabel 5. Persepsi karyawan terhadap motivator

\begin{tabular}{|c|c|c|c|c|c|c|c|c|}
\hline \multirow{2}{*}{ Indikator variabel motivator } & \multicolumn{5}{|c|}{ Jumlah jawaban } & \multirow{2}{*}{ Total skor } & \multirow{2}{*}{ Rataan skor } & \multirow{2}{*}{ Keterangar } \\
\hline & 1 & 2 & 3 & 4 & 5 & & & \\
\hline Pengakuan & 2 & 19 & 112 & 88 & 61 & 1033 & 3,66 & Tinggi \\
\hline Pekerjaan itu sendiri & 7 & 17 & 88 & 106 & 64 & 1049 & 3,72 & Tinggi \\
\hline Tanggungjawab & 3 & 19 & 112 & 171 & 165 & 1886 & 4,01 & Tinggi \\
\hline Peluang untuk maju & 5 & 7 & 84 & 108 & 78 & 1093 & 3,88 & Tinggi \\
\hline Prestasi yang diraih & 24 & 22 & 164 & 251 & 197 & 2549 & 3,87 & Tinggi \\
\hline Total & & & & & & & 3,83 & Tinggi \\
\hline
\end{tabular}

Tabel 6. Persepsi karyawan terhadap hygiene factor

\begin{tabular}{|c|c|c|c|c|c|c|c|c|}
\hline \multirow{2}{*}{$\begin{array}{l}\text { Indikator variabel } \\
\text { hygiene factor }\end{array}$} & \multicolumn{5}{|c|}{ Jumlah jawaban } & \multirow{2}{*}{ Total skor } & \multirow{2}{*}{ Rataan skor } & \multirow{2}{*}{ Keterangan } \\
\hline & 1 & 2 & 3 & 4 & 5 & & & \\
\hline Prosedur perusahaan & 7 & 14 & 218 & 350 & 257 & 3374 & 3,99 & Tinggi \\
\hline Kondisi kerja & 30 & 46 & 252 & 301 & 405 & 4107 & 3,97 & Tinggi \\
\hline Upah/gaji & 11 & 26 & 128 & 126 & 85 & 1376 & 3,66 & Tinggi \\
\hline Mutu penyeliaan & 8 & 30 & 120 & 142 & 76 & 1376 & 3,66 & Tinggi \\
\hline Hubungan interpersonal & 22 & 25 & 136 & 247 & 134 & 2138 & 3,79 & Tinggi \\
\hline Total & & & & & & & 3,81 & Tinggi \\
\hline
\end{tabular}

Tabel 7. Persepsi karyawan terhadap kinerja

\begin{tabular}{|c|c|c|c|c|c|c|c|c|}
\hline \multirow{2}{*}{$\begin{array}{c}\text { Indikator variabel } \\
\text { kinerja }\end{array}$} & \multicolumn{5}{|c|}{ Jumlah jawaban } & \multirow{2}{*}{ Total skor } & \multirow{2}{*}{ Rataan skor } & \multirow{2}{*}{ Keterangan } \\
\hline & 1 & 2 & 3 & 4 & 5 & & & \\
\hline Kuantitas & 12 & 15 & 259 & 331 & 229 & 3288 & 3,887 & Tinggi \\
\hline Kualitas & 17 & 17 & 332 & 469 & 293 & 4388 & 3,890 & Tinggi \\
\hline Total & & & & & & & 3,888 & Tinggi \\
\hline
\end{tabular}




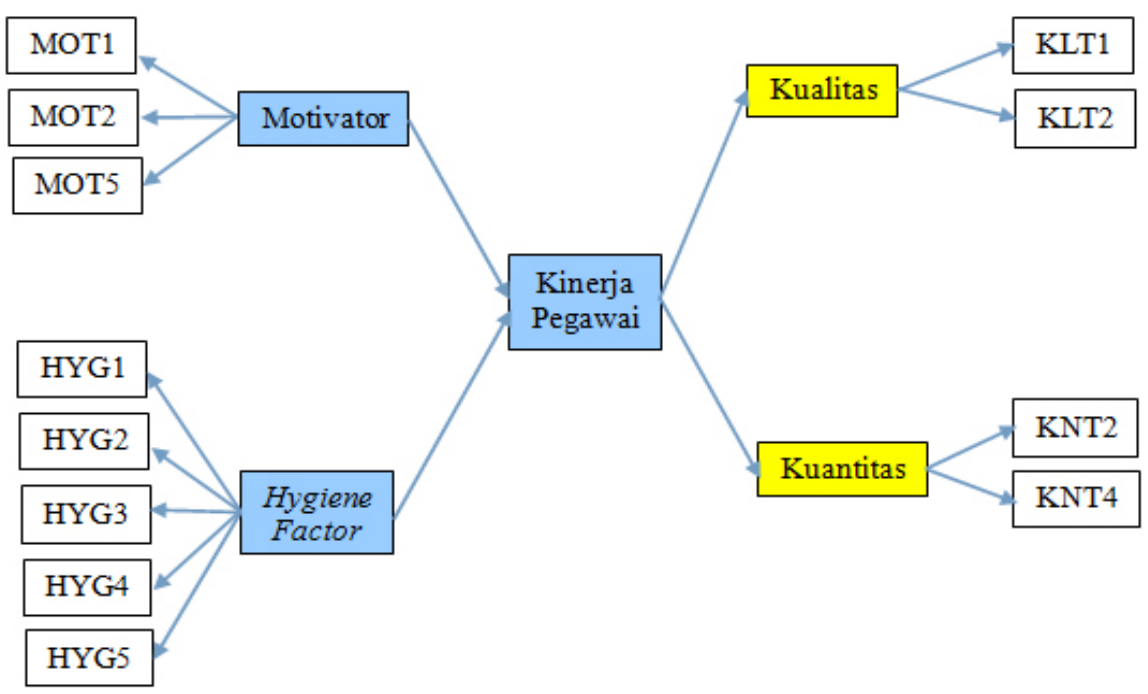

Gambar 2. Hasil pengujian convergent validity

\section{Evaluasi Inner Model dan Outer Model}

Evaluasi model pengukuran (outer model) dilakukan dengan menguji validitas dan reliabilitas. Validitas menunjukkan sejauh mana ketepatan dan kecermatan suatu alat ukur dalam melakukan fungsi ukurnya (Widodo, 2006). Sedangkan reliabilitas berarti sejauh mana hasil suatu pengukuran dapat dipercaya dengan melihat danya konsistensi dan stabilitas nilai hasil skala pengukuran tertentu (Matondang, 2009). Hasil pengujian validitas konvergen berupa nilai loading factor dan AVE (Average variance extracted). Nilai loading factor semua indikator dikatakan valid apabila $>0,5$ (Ghozali, 2006). Model penelitian dapat dikatakan baik jika AVE masing-masing konstruk nilainya $>0,5$.

Pada penelitian ini terdapat beberapa indikator yang harus dihilangkan agar nilai AVE yang diperoleh $>0,5$ dan model penelitian ini dikatakan valid. Indikatorindikator yang dihilangkan adalah prestasi yang diraih, jumlah dan jenis pemberian layanan, pengakuan, kemampuan menganalisis data dan informasi, proses kerja, serta ketepatan kerja dan kualitas pekerjaan. Hasil yang diperoleh pada penelitian ini dapat dilihat pada Gambar 2.

Hubungan antara motivator dengan kinerja pegawai adalah signifikan dengan t-statistik sebesar 4,668709 $(>1,96)$. Nilai original sample estimate adalah positif $(0,311290)$ yang menunjukkan bahwa arah hubungan antara motivator dengan kinerja pegawai adalah positif. Dengan demikian hipotesis 1 dalam penelitian ini yang menyatakan bahwa "motivator berpengaruh terhadap kinerja pegawai" diterima. Hubungan antara hygiene factor dengan kinerja pegawai adalah signifikan dengan t-statistik sebesar 7,559212 (>1,96). Nilai original sample estimate adalah positif yaitu sebesar 0,454101 yang menunjukkan bahwa arah hubungan antara hygiene factor dengan kinerja pegawai adalah positif. Dengan demikian hipotesis 2 dalam penelitian ini yang menyatakan bahwa "hygiene factor berpengaruh positif dan signifikan terhadap kinerja pegawai" diterima. Hal ini sesuai dengan hasil penelitian yang dilakukan oleh Handayani (2015) yang menyatakan bahwa motivator maupun hygiene factor keduanya memberikan pengaruh terhadap kinerja pegawai. Agusta dan Sutanto (2013) dalam penelitiannya juga memperoleh hasil bahwa motivasi kerja berpengaruh positif dan signifikan terhadap kinerja karyawan. Berdasarkan nilai original sample estimate terlihat bahwa hygiene factor memiliki pengaruh yang lebih dominan terhadap kinerja pegawai sebesar 0,454 dibandingkan dengan motivator sebesar 0,311 .

Uji berikutnya adalah uji validitas discriminant melalui nilai akar Average Variance Extracted (AVE) yang harus bernilai lebih besar dari nilai korelasi antar konstruk. Terlihat pada Tabel 8, konstruk dalam model yang diestimasi memenuhi kriteria discriminant validity.

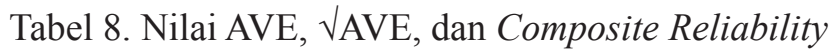

\begin{tabular}{lccc}
\hline & AVE & VAVE & $\begin{array}{c}\text { Composite } \\
\text { reliability }\end{array}$ \\
\hline Hygiene Faktor & 0,5387 & 0,73396 & 0,851654 \\
Kinerja Pegawai & 0,5519 & 0,74289 & 0,829212 \\
Kualitas & 0,7231 & 0,85034 & 0,838795 \\
Kuantitas & 0,6869 & 0,82877 & 0,814327 \\
Motivator & 0,5026 & 0,70891 & 0,751085 \\
\hline
\end{tabular}


Uji reliabilitas digunakan untuk mengetahui kesamaan jawaban yang diberikan dari setiap pertanyaan yang diajukan secara berulang. Uji ini digunakan untuk melihat konsistensi jawaban yang diberikan. Pengujian reliabilitas dari suatu variabel dapat dilakukan dengan melihat nilai Composite Reliability. Menurut Ghozali (2006) suatu instrumen dikatakan handal apabila nilai Composite Reliability > 0,70. Berdasarkan hasil perhitungan pada Tabel 4 diketahui bahwa koefisien Composite Reliabilty untuk variabel motivator, hygiene factor dan kinerja pegawai berada di atas 0,70 yang menunjukkan bahwa semua instrumen adalah reliabel (handal) untuk dijadikan sebagai parameter pengujian selanjutnya.

Setelah model yang diestimasi memenuhi kriteria outer model, berikutnya dilakukan pengujian model struktural (inner model). R-square berfungsi menjelaskan kemampuan independent variable dalam menjelaskan dependent variable. Semakin tinggi nilai $\mathrm{R}$-square maka semakin besar kemampuan variabel independen tersebut dapat menjelaskan variabel dependen. Nilai R-square konstruk adalah 0,496519 pada kinerja pegawai yang dipengaruhi oleh motivator dan hygiene factor. Hasil tersebut menunjukkan bahwa variabilitas kinerja pegawai yang dapat dijelaskan oleh model adalah sebesar $49,65 \%$ sedangkan sisanya $50,35 \%$ dijelaskan oleh variabel lain diluar yang diteliti.

\section{Faktor-faktor Motivasi yang Berpengaruh terhadap Kinerja Pegawai}

Indikator kondisi kerja dan hubungan interpersonal merupakan indikator yang paling dominan dalam merefleksikan variabel hygiene factor dibandingkan indikator-indikator lainnya. Terlihat dari angka loading factor untuk indikator kondisi kerja sebesar 0,820 dan loading factor untuk indikator hubungan interpersonal sebesar 0,816. Hal ini sesuai dengan hasil penelitian Handayani (2014) bahwa kondisi kerja adalah salah satu indikator yang paling dominan merefleksikan hygiene factor dalam membentuk kinerja pegawai. Menurut Djumadi (2006) kondisi kerja adalah kondisi tempat kerja dimana pegawai melakukan pekerjaannya. Kondisi kerja merupakan segala sesuatu yang ada di lingkungan kerja pegawai yang dapat Memengaruhi dirinya dalam menjalankan tugas, seperti temperatur, kelembaban, ventilasi, penerangan, kebisingan, kebersihan tempat kerja, dan kondisi peralatan untuk bekerja (Salutondok dan Soegoto, 2015). Berkaitan dengan kondisi kerja menurut Khan (2011) bahwa kondisi kerja yang aman, menguntungkan, dan memuaskan juga berkontribusi untuk meningkatkan motivasi pegawai terhadap pekerjaan. Saat pegawai bekerja pada suatu kondisi kerja yang bersih dan nyaman maka akan memengaruhi motivasi kerja dan kinerja pegawai. Kondisi kerja yang nyaman berpengaruh dalam mengurangi rasa cepat lelah, mengurangi kebosanan sehingga semangat kerja meningkat, membuat pegawai betah di tempat kerja dan bertanggungjawab dalam melaksanakan tugasnya (Nur et al. 2013).

Selain kondisi kerja, hubungan interpersonal juga merupakan indikator yang paling dominan merefleksikan hygiene factor dalam membentuk kinerja pegawai. Hubungan interpersonal didefinisikan sebagai interaksi antar individu dalam berperilaku berdasarkan situasi lingkungan, reaksi orang lain, kepercayaan, sikap dan kepentingan individu (Snyder, 1974). Untuk menjalin hubungan interpersonal yang baik di antara rekan kerja diperlukan rasa saling percaya, terjalin komunikasi yang baik, kemampuan untuk dapat memberi maupun menerima masukan, dan kemampuan menyelesaikan masalah dengan baik (Moningka dan Widyarini, 2005). Hubungan antar manusia dalam organisasi perlu dibina untuk mencegah timbulnya konflik terutama konflik antar pribadi dalam organisasi tersebut yang dapat merugikan kelangsungan aktivitas organisasi. Manfaat dari hubungan antar pribadi yang baik pada suatu organisasi adalah setiap masalah dapat diselesaikan secara kekeluargaan, adanya sikap saling menghargai dan percaya antar rekan kerja, dan pelaksanaan pekerjaan dapat dilakukan dengan suasana yang penuh keakraban.

Indikator pekerjaan itu sendiri merupakan indikator yang paling dominan dalam merefleksikan motivator dibandingkan indikator-indikator lainnya. Terlihat dari angka loading factor untuk indikator pekerjaan itu sendiri sebesar 0,770. Pengaruh faktor pekerjaan itu sendiri terhadap kinerja karyawan dinyatakan oleh Kuswandi (2004) bahwa orang akan bekerja lebih untuk apa yang disukai dan kurang untuk apa yang kurang disukai sehingga orang yang bekerja sesuai dengan minatnya dengan kata lain menyenangi pekerjaannya akan lebih produktif dalam bekerja daripada pegawai yang tidak menyukai pekerjaannya. Hal tersebut sejalan dengan apa yang diungkapkan oleh Almigo (2004) bahwa tingkat produktivitas karyawan dalam bekerja ditentukan oleh minat dan kompetensi yang dimiliki sehingga perusahaan perlu mengetahui hal 
tersebut agar pegawai dapat bekerja secara produktif demi tercapainya tujuan perusahaan. Organisasi harus bersedia mencocokan apa yang diinginkan pegawai dengan apa yang akan diberikan dan dilakukan oleh organisasi (Aghazadeh, 1999).

\section{Implikasi Manajerial}

Motivasi kerja yang paling besar pengaruhnya terhadap kinerja pegawai PT. Bank BNI Syariah Kantor Cabang Jakarta Barat dan Bogor adalah hygiene factor. Hal ini menunjukkan bahwa pegawai akan termotivasi untuk meningkatkan kinerjanya jika pemenuhan kebutuhan terhadap hygiene factor dapat terpenuhi. Hasil penelitian, kondisi kerja dan hubungan interpersonal merupakan indikator yang paling dominan dalam merefleksikan variabel hygiene factor. Kondisi pekerjaan meliputi tempat bekerja, fasilitas dan alat bantu pekerjaan, kebersihan, pencahayaan, ketenangan, termasuk juga hubungan kerja antara orang-orang yang ada pada organisasi tersebut. Organisasi perlu melakukan beberapa upaya diantaranya memanfaatkan sarana dan prasarana yang ada untuk mencapai kinerja pegawai sesuai dengan target yang sudah diberikan organisasi, memelihara sarana dan prasarana yang sudah ada pada setiap ruangan dan kantor, memperhatikan aspek pencahayaan, kebersihan, sirkulasi udara dan kepadatan jumlah pegawai di setiap ruangan sehingga pegawai tetap dalam kondisi nyaman saat bekerja. Organisasi juga dapat mengadakan rapat koordinasi antara kepala bagian umum di cabang dengan seluruh pegawai mengenai sarana dan prasarana yang dibutuhkan untuk menunjang kegiatan pekerjaan pegawai sehari-hari. Terpenuhinya sarana dan prasarana penunjang yang dibutuhkan oleh pegawai akan berdampak pada kelancaran pelaksanaan tugas sehingga dapat meningkatkan kinerja pegawai.

Selain kondisi kerja, hubungan interpersonal juga merupakanindikatoryangpalingdominanmerefleksikan hygiene factor dalam membentuk kinerja pegawai. Indikator hubungan interpersonal yang terdiri dari saling menghargai, toleran, loyal, saling terbuka dan akrab antar sesama rekan kerja mampu meningkatkan hygiene factor sehingga dapat meningkatkan kinerja pegawai. Organisasi dapat mengadakan acara family gathering, employee gathering maupun pertemuan non formal seperti sarapan bersama yang dapat memperlancar komunikasi dan keakraban diantara sesama rekan kerja. Dengan adanya beberapa kegiatan yang melibatkan seluruh pegawai, diharapkan komunikasi antar pegawai semakin lancar, baik dalam hubungan kerja maupun hubungan pertemanan. Pegawai juga dihimbau untuk saling bersikap terbuka terhadap saran dari rekan kerja lain dan mau menerima masukan yang membangun sehingga kinerja pegawai dapat ditingkatkan.

Faktor pekerjaan itu sendiri merupakan indikator yang paling dominan dalam merefleksikan variabel motivator. Upaya yang dapat dilakukan oleh organisasi di antaranya membuat angket atau Kuesioner terkait kesesuaian antara minat kerja dengan posisi atau jabatan yang ditempati pegawai saat ini. Organisasi juga dapat melakukan pendataan kesesuaian latar belakang pendidikan dengan jabatan pegawai yang ditempati saat ini. Apabila terdapat pegawai yang tidak sesuai antara latar belakang pendidikan dengan jabatan yang diembannya saat ini maka dapat diusulkan rotasi di dalam organisasi. Organisasi juga perlu membuat pemetaan karir pegawai berdasarkan pada minat, prestasi kerja, dan latar belakang pendidikan pegawai sehingga diharapkan tercipta kondisi the right man on the right place. Penempatan pegawai pada setiap posisi dan jabatan diharapkan sesuai dengan minat pegawai sehingga tercipta rasa meyukai dan memiliki terhadap pekerjaannya sehingga diharapkan akan meningkatkan produktivitas kerja dan kinerja pegawai.

\section{KESIMPULAN DAN SARAN}

\section{Kesimpulan}

Persepsi responden pada PT. Bank BNI Syariah Kantor Cabang Jakarta Barat dan Bogor terhadap variabel-variabel penelitian yaitu motivator, hygiene factor, dan kinerja pegawai sudah baik, namun belum maksimal sehingga organisasi masih perlu melakukan upaya untuk meningkatkan motivasi kerja pegawai sehingga kinerja pegawai dapat menjadi lebih baik. Motivator dan hygiene factor keduanya berpengaruh positif dan signifikan terhadap kinerja pegawai di PT. Bank BNI Syariah Kantor Cabang Jakarta Barat dan Bogor. Terdapat dua faktor yang paling dominan dalam merefleksikan hygiene factor yaitu kondisi kerja dan hubungan interpersonal. Sedangkan faktor yang paling dominan dalam merefleksikan motivator adalah pekerjaan itu sendiri. 


\section{Saran}

Meningkatkan hygiene factor melalui perbaikan kondisi kerja meliputi kenyamanan ruang kerja, terpenuhinya sarana dan prasarana yang dapat menunjang pekerjaan, fasilitas kantor yang memadai, kebersihan ruangan, pencahayaan yang cukup, ketenangan, dan sirkulasi udara yang baik. Ruangan kerja juga dapat dibuat agar tidak terlalu padat sehingga mobilitas para pegawai tetap terjaga dengan baik dan pegawai merasa nyaman saat bekerja. Perbaikan juga perlu dilakukan terkait hubungan interpersonal antar pegawai dengan mengadakan berbagai acara bersama seperti family gathering, employee gathering dan berbagai acara non formal lainnya yang dapat meningkatkan keakraban sehingga komunikasi antar pegawai menjadi lebih baik. Meningkatkan motivator melalui pemetaan karir pegawai berdasarkan pada minat, kemampuan, prestasi kerja, dan latar belakang pendidikan pegawai sehingga diharapkan tercipta kondisi the right man on the right place. Perlu adanya penelitian lebih lanjut khususnya terkait dengan faktor-faktor motivasi yang digunakan disarankan agar menggunakan faktor-faktor motivasi dari teori motivasi lainnya. Kriteria kinerja pegawai dapat diambil dari data perusahaan berupa skor KPI (Key Performance Indicator) tahunan karyawan dan dapat juga ditambah variabel kinerja perusahaan dengan menggunakan data pada laporan tahunan perusahaan.

\section{DAFTAR PUSTAKA}

Aghazadeh SM. 1999. Human resource management: issues and challenges in the new millenium. Management Research News 22(12):1-3.

Agusta L, Sutanto EM. 2013. Pengaruh pelatihan dan motivasi kerja terhadap kinerja karyawan CV Haragon Surabaya. Jurnal AGORA 1(3): 13991408.

Almigo, Nuzsep. 2004. Hubungan antara kepuasan kerja dan kinerja karyawan. Jurnal Psyche 1(1): 611-628.

Djumadi. 2006. Pengaruh kondisi kerja dan kepuasan kerja terhadap kinerja karyawan lembaga pendidikan nonformal di Jawa Timur. Jurnal Aplikasi Manajemen 4(3):441-420.

Fajri LL, Maarif S, Sumarwan U. 2016. Pendekatan budaya kerja untuk mengurangi ketidakselarasan antar divisi pada Batik Bogor Tradisiku. Jurnal Manajemen dan Agribisnis 13(3): 217-226.
Feng YJ, Tong XH, Liu ML. 2008. Partial least squares regression based cellular automata model for simulating complex urban systems. The International Archives of the Photogrammetry, Remote Sensing and Spatial Information Sciences 37(2):19-24

Ghozali PD. 2006. Structural Equation Modeling Metode Alternatif Dengan Partial Least Square. Semarang: Universitas Diponegoro.

Ghozali I, H Latan. 2015. Konsep, Teknik dan Aplikasi menggunakan Program SmartPLS 3.0. Ed. ke-2. Semarang: Badan Penerbit Universitas Diponegoro.

Hacker M, Doolen T. 2007. Alignment at the top: a case study investigating this critical factor in project implementation. Engineering Management Journal 19(1): 38-42.

Hamid ES, B Rowi. 2003. Membangun Profesional Muhammadiyah. Yogyakarta: LPTP Muhammadiyah dan UAD Press.

Handayani PD, Hutagaol MP, Affandi MJ. 2015. Pengaruh faktor-faktor motivasi terhadap kinerja pegawai dinas bina marga dan sumber daya air Kota Bogor. Jurnal Aplikasi Manajemen 13(3):538-546

Hays MJ, Hill VA. 1999. Gaining competitive service value through performance motivation. Journal of Strategic Performance Measurement 10(1): 36-40

Haenlein M, Kaplan AM. 2004. A beginner's guide to partial least square analysis. Journal Understanding Statistics 3(4):283-297.

Herzberg F, B Mausner, BB Snyderman. 2008. The Motivations to Work. Ed. ke-11. New York: John Wiley \& Sons, Inc.

Khan. 2011. The impact of work content, working conditions, career growth on employee motivation. Interdisciplinary Journal of Contemporary Research in Business 3(3):14281434.

Koesmono HT. 2005. Pengaruh budaya organisasi terhadap motivasi dan kepuasan kerja serta kinerja karyawan pada sub sektor industri pengolahan kayu skala menengah di Jawa Timur. Jurnal Manajemen dan Kewirausahaan 7(2):171-188.

Kolina N, Mustamu RH. 2013. Analisis deskriptif strategi bersaing pada perusahaan manufaktur plastik. Jurnal AGORA 1(1):1-13.

Kurniawan AW. 2009. Pengaruh kepemimpinan dan pengembangan sumber daya manusia terhadap 
kepuasan kerja, motivasi kerja, dan kinerja karyawan Bank Sulselbar. Jurnal Universitas Negeri Makassar 1-21

Kuswandi. 2004. Cara Mengukur Kepuasan Karyawan. Jakarta: Gramedia Pustaka Utama.

Lusthaus C. 2002. Enchancing Organizational Performance: A toolbox for Self-Asessment. Canada: International Development Research Centre.

Mangkunegara AP. 2004. Evaluasi Kinerja Sumber Daya Manusia. Bandung: PT. Refika Aditama

Matondang Z. 2009. Validitas dan reliabilitas suatu instrumen penelitian. Jurnal Tabularasa PPS Unimed 6(1):87-97.

Moningka C, Widyarini MN. 2005. Pengaruh hubungan interpersonal, self monitoring, dan minat terhadap performansi kerja pada karyawan bagian penjualan. Di dalam: Proceeding Seminar Nasional PESAT; Jakarta,23-24 Agustus 2005. Jakarta: Universitas Gunadarma. Hlm 146-158.

Muljani N. 2002. Kompensasi sebagai motivator untuk meningkatkan kinerja karyawan. Jurnal Manajemen \& Kewirausahaan 4(2):108-122.

Muslih B, Troena EA, Rohman F. 2012. Analisis pengaruh motivasi terhadap kepuasan kerja dan kinerja pegawai di PT Sang Hyang Seri (Persero) regional III Malang. Jurnal Aplikasi Manajemen 10(4):799-810.

Noermijati. 2008. Kajian terhadap dua faktor herzberg, pengaruhnya terhadap kepuasan kerja dan kinerja spiritual manajer operasional pada perusahaan kecil rokok SKT di kota dan kabupaten Malang. Di dalam: National Conference on Management Research; Makassar, 27 November 2008. Hlm $1-18$.

Nur J, Siburian PS, Robiansyah. 2013. Pengaruh hubungan interpersonal dan lingkungan kerja terhadap kepuasan kerja pegawai dinas kebudayaan dan pariwisata provinsi kalimantan timur. Jurnal Universitas Mulawarman 1(1): $1-25$.

Salutondok Y, Soegoto AS. 2015. Pengaruh kepemimpinan, motivasi, kondisi kerja dan disiplin terhadap kinerja pegawai di kantor sekretariat DPRD Kota Sorong. Jurnal EMBA 3(3):849-862.

Snyder M. 1974. Self monitoring of expressive behaviour. Journal of Personality and Social Psychology 49(3):586-597.

Suprapti AR. 2008. Hubungan motivasi mengikuti pelatihan dan kinerja karyawan dengan orientasi pembelajaran sebagai variabel pemediasi. Jurnal Bisnis dan Manajemen 8(2):131-136.

Werther, Davis K. 1996. Human Resource and Personal Management Ed. Ke-5. USA: McGraw Hill, Inc Wibowo CT. 2015. Analisis pengaruh kecerdasan emosional (EQ) dan kecerdasan spiritual (SQ) pada kinerja karyawan. Jurnal Bisnis dan Manajemen 15(1):1-14.

Widodo PB. 2006. Reliabilitas dan validitas konstruk skala konsep diri untuk mahasiswa Indonesia. Jurnal Psikologi Universitas Diponegoro 3(1):1-9. 